\title{
Palladium Polypyridyl Complexes: Synthesis, Characterization, DNA Interaction and Biological Activity on Leishmania (L.) mexicana
}

\author{
Maribel Navarro, ${ }^{*, a}$ Adelmo Betancourt, ${ }^{b}$ Clara Hernández $z^{c}$ and Edgar Marchán ${ }^{d}$ \\ ${ }^{a}$ Centro de Química, Instituto Venezolano de Investigaciones Científicas, Caracas 1020-A, Venezuela \\ ${ }^{b}$ Departamento de Química, Facultad Experimental de Ciencia y Tecnología,
} Universidad de Carabobo, Valencia, Venezuela

'Departamento de Ciencias Básicas, Escuela de Bioanálisis, Facultad de Ciencias de La Salud, Universidad de Carabobo Sede Aragua, Maracay, Venezuela

${ }^{d}$ Instituto de Investigaciones en Biomedicina y Ciencias Aplicadas, Universidad de Oriente, Núcleo de Sucre, Cumaná 6101, Venezuela

\begin{abstract}
Este trabalho descreve a busca de novos agentes com potencial quimioterápico baseados em complexos de metais de transição com ligantes planares. Neste estudo, complexos polipiridilpaládio foram sintetizados e caracterizados por análise elementar e por espectroscopias de RMN e de absorção no UV-visível e no infravermelho. A interação dos complexos com DNA também foi investigada por métodos espectroscópicos. Todas as bandas de transferência de carga do metal para os ligantes (TCML) dos complexos polipiridilpaládio exibiram hipocromismo e deslocamento para o vermelho na presença de DNA. A constante de formação e os dados de viscosidade sugeriram que os complexos $\left[\mathrm{PdCl}_{2}\right.$ (phen) $]$ e $\left[\mathrm{PdCl}_{2}\right.$ (phendiamine) $]$ interagem com DNA por forças eletrostáticas. Adicionalmente, estes complexos induziram um efeito leishmaniostático importante sobre promastigotos de $L$. (L.) mexicana na concentração final de $10 \mu \mathrm{mol} \mathrm{L}^{-1} \mathrm{em} 48 \mathrm{~h}$.
\end{abstract}

This paper describes the search for new potential chemotherapeutic agents based on transition metal complexes with planar ligands. In this study, palladium polypyridyl complexes were synthesized and characterized by elemental analysis, NMR, UV-VIS and IR spectroscopies. The interaction of the complexes with DNA was also investigated by spectroscopic methods. All metal-to-ligand charge transfer (MLCT) bands of the palladium polypyridyl complexes exhibited hypochromism and red shift in the presence of DNA. The binding constant and viscosity data suggested that the complexes $\left[\mathrm{PdCl}_{2}(\mathrm{phen})\right]$ and $\left[\mathrm{PdCl}_{2}(\right.$ phendiamine $\left.)\right]$ interact with DNA by electrostatic forces. Additionally, these complexes induced an important leishmanistatic effect on L. (L.) mexicana promastigotes at the final concentration of $10 \mu \mathrm{mol} \mathrm{L}^{-1}$ in $48 \mathrm{~h}$.

Keywords: palladium complexes, polypyridyl, Leishmania (L.) mexicana

\section{Introduction}

Leishmaniasis comprises a group of diseases with extensive morbidity and mortality in most developing countries. They are caused by a species of the genus Leishmania (Sarcomastigophora, Kinetoplastida) and range from self-healing cutaneous leishmaniasis (CL) to progressive mucocutaneous infections (MCL) or fatal disseminating visceral leishmaniasis (VL). While CL basically produces cosmetic problems and MCL leads

*e-mail: mnavarro@ivic.ve to painful disfiguration, social stigmatization and often severe secondary infections, VL is generally lethal if left untreated. According to the World Health Organization, leishmaniasis currently affects some 12 million people worldwide, with 2 million new cases per year, and that number is growing. Moreover, it is estimated that approximately 350 million people live at risk of infection with Leishmania parasites. Leishmaniasis is prevalent in 88 countries throughout the world in tropical to Mediterranean climate zones, including 22 in the New World and 66 in the Old World. Included in this number are 72 developing countries. ${ }^{1}$ 
The available treatment is based on organic pentavalent antimony compounds that produce severe side effects such as cardiotoxicity, reversible renal insufficiency, pancreatitis, anemia, leucopenia, rashes, headache, abdominal pain, nausea, vomiting, thrombocytopenia, and transaminase elevation. $^{2}$

The parasites of the genus Leishmania, along with those of the genus Trypanosoma, belong to Order Kinetoplastide and are considered to behave in a way similar to tumoral cells with regard to drug sensitivity and cell multiplication. ${ }^{3,4}$ Cisplatin and other metal-containing antitumoral compounds have been tested against Leishmania spp with interesting results in the search for new and more effective chemotherapeutic treatments. Based on these results and because it is known that this kind of compound interacts with DNA, it has been proposed that all DNA-interacting compounds might show activity against protozoa. ${ }^{5}$

Additionally, in the development of new pharmaceutics against tropical diseases, some effort have been directed to the synthesis and characterization of complexes of transition metals with different organic drugs such as pentadiamine, chloroquine, clotrimazole, and ketoconazole as ligands, and that have been evaluated against malaria, trypanosomiasis and leishmaniasis. ${ }^{6-11}$

The strategy in pursuing the search for new drugs that combine high activity and low toxicity has been the coordination of planar ligands to palladium. This may result in an interesting biological activity because of the possible ability of the new metal complexes to inhibit DNA replication through single or simultaneous interactions such as intercalation and/or covalent coordination to DNA. ${ }^{12-13}$

The interest in the use of palladium in the development of antitumoral drugs arises from the fact that this metal is isoelectronic with platinum, a metal used with great success as an antitumor agent. It has been reported that palladium complexes, such as trans-palladium complexed to a bulky amine ligand, showed a higher activity against the L929 cell line when compared with carboplatin. ${ }^{14}$ Also, trans- $\left[\mathrm{PdCl}_{2}(\mathrm{~L})_{2}\right]$, where $\mathrm{L}$ is a highly substituted pyrazole ligand, was more cytotoxic than cis-platinum with the same ligand, although less cytotoxic than cisplatin. ${ }^{10}$ Additionally, the cytotoxic activity of chloroquine, clotrimazole, thiosemicarbazones and their palladium complexes was tested against human tumor cell lines with encouraging results. ${ }^{15-18}$

In the previous papers of this series, copper-dipyrido [3,2-a: 2',3'-c]phenazine (dppz) and copper-dipyrido[3,2-d: 2',3'-f]quinoxaline (dpq) complexes were obtained, that have shown interaction with DNA and high activity against Leishmania parasites associated with the interaction between the metal complexes and DNA. Continuing the search for new drugs with similar characteristics, it was decided to investigate the activity of palladium-planar ligand complexes against this parasite. ${ }^{19-22}$

In this study the synthesis and characterization of palladium(II) complexes, including studies of their interaction with DNA and in vitro evaluation of their activity on Leishmania (L.) mexicana promastigotes is presented.

\section{Results and Discussion}

The complexes 1-5 were synthesized by reaction of $\left[\mathrm{PdCl}_{2}\left(\mathrm{C}_{6} \mathrm{H}_{5} \mathrm{CN}\right)_{2}\right]$ with their respective planar free ligand in dichloromethane or acetonitrile as mentioned in the experimental section. The organic ligands displaced the labile $\mathrm{C}_{6} \mathrm{H}_{5} \mathrm{CN}$ molecules from the starting complex, $\left[\mathrm{PdCl}_{2}\left(\mathrm{C}_{6} \mathrm{H}_{5} \mathrm{CN}\right)_{2}\right]$. The products were characterized by elemental analysis and spectroscopic techniques. The elemental analyses of all complexes showed the presence of one planar ligand molecule and two chlorides. The IR spectra of the complexes displayed peaks clearly associated with the presence of the polypyridyl ligands. All ${ }^{1} \mathrm{H}$ NMR resonances were assigned on the basis of 1D experiments for complexes 1-3. The hydrogen of the polypyridyl ligands is shifted to a higher frequency with respect to the proligand, indicating complexation. Unfortunately complexes $\mathbf{4}$ and $\mathbf{5}$ are not soluble in any solvent. According to the analytical and NMR data and by analogy with reported complexes, ${ }^{23}$ these complexes must possess a tetracoordinate 16-electron palladium(II) configuration.

\section{DNA interaction studies}

The interaction of complexes 1-3 with DNA causes electronic perturbations in the complexes. These perturbations can be observed through emission studies and spectroscopic titration. The emission spectra for these complexes were similar. As an example, the emission spectra for complex 1 (Figure 1) are shown. It emits luminescence in a buffer at room temperature with a maximum at $677 \mathrm{~nm}$. The luminescent properties of the complexes were perturbed when DNA was titrated with the palladium complex solution, and binding of the complex to DNA was found to increase the luminescence intensity. Upon addition of CT DNA, the emission increased 4-fold. This implies that these complexes can interact with CT DNA. ${ }^{24}$

The UV-absorption spectra of complexes 1-3 with increasing concentration of CT DNA are shown in Figure 2. For these complexes, hypochromicity was observed (Table 1), although no obvious red shift was found for complexes 

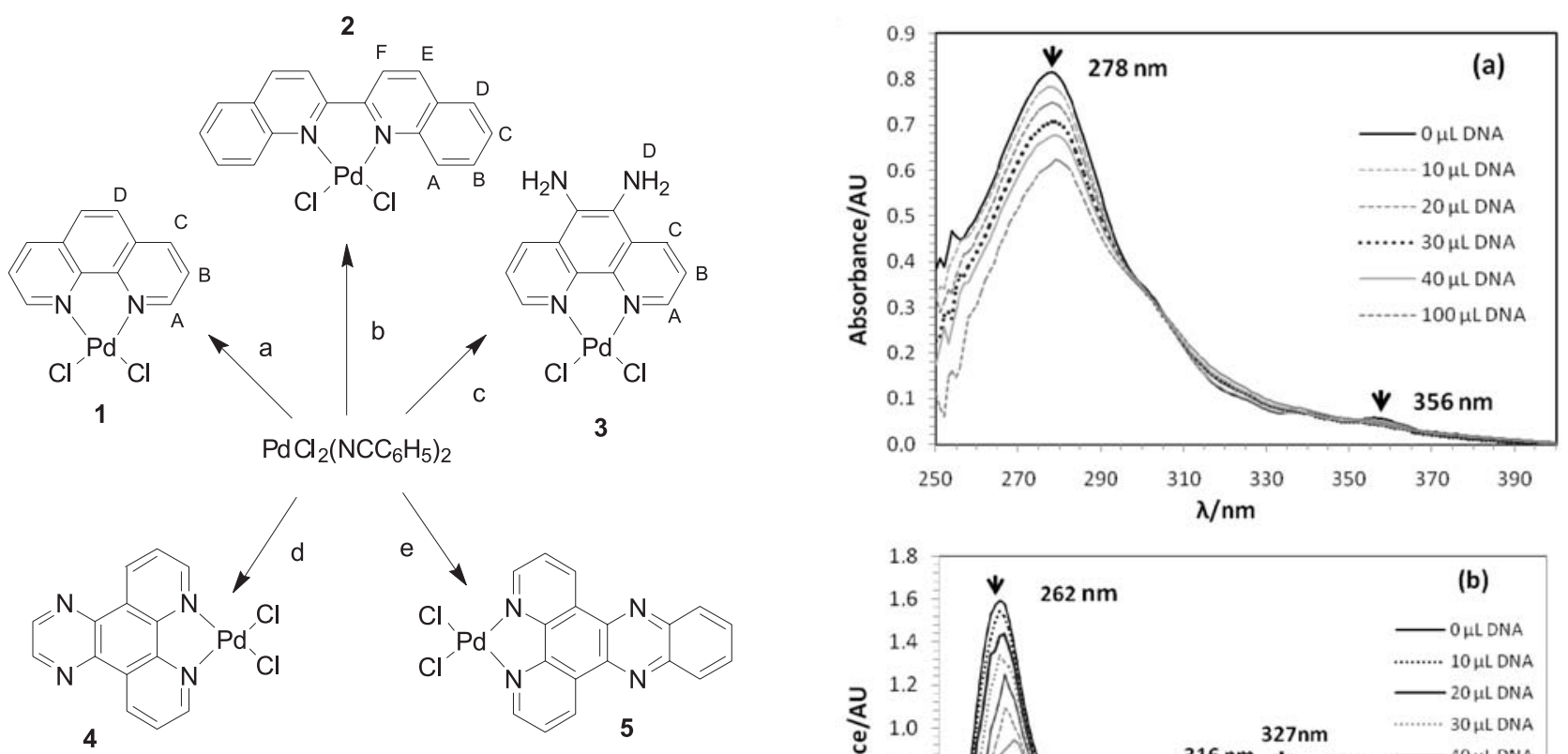

Scheme 1. Synthesis of palladium polypyridyl complexes: a) $\left[\mathrm{PdCl}_{2}\left(\mathrm{NCC}_{6} \mathrm{H}_{5}\right)_{2}\right] / \mathrm{Phenantroline} / \mathrm{CH}_{2} \mathrm{Cl}_{2}$ at $40-45^{\circ} \mathrm{C}$ for $2 \mathrm{~h}$. b) $\left[\mathrm{PdCl}_{2}\left(\mathrm{NCC}_{6} \mathrm{H}_{5}\right)_{2}\right] / \mathrm{CH}_{2} \mathrm{Cl}_{2} / 2,2$-biquinoline at $40-45{ }^{\circ} \mathrm{C}$ for 1 h. c) $\left[\mathrm{PdCl}_{2}\left(\mathrm{NCC}_{6} \mathrm{H}_{5}\right)_{2}\right] / \mathrm{CH}_{3} \mathrm{CN} /$ phediamine at $55^{\circ} \mathrm{C}$ for $4 \mathrm{~h}$. d) $\left[\mathrm{PdCl}_{2}\left(\mathrm{NCC}_{6} \mathrm{H}_{5}\right)_{2}\right] / \mathrm{CH}_{2} \mathrm{Cl}_{2} / \mathrm{dpq}$ at $40-45^{\circ} \mathrm{C}$ for 2 h. e) $\left[\mathrm{PdCl}_{2}\left(\mathrm{NCC}_{6} \mathrm{H}_{5}\right)_{2}\right] /$ $\mathrm{CH}_{2} \mathrm{Cl}_{2} / \mathrm{dppz}$ at $40-45^{\circ} \mathrm{C}$ for $3 \mathrm{~h}$.

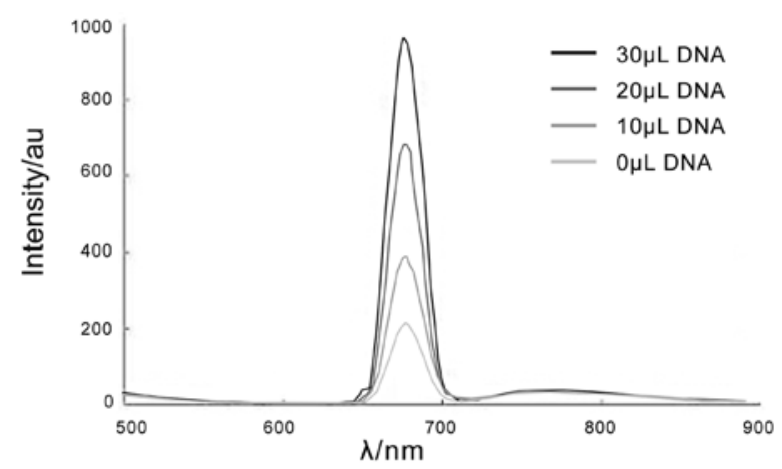

Figure 1. Emission spectra of complex 1 in the presence of increasing amounts of CT-DNA. [Complex] $=2 \times 10^{-4} \mathrm{~mol} \mathrm{~L}^{-1}$, $[\mathrm{DNA}]=1 \mathrm{mg} \mathrm{mL}^{-1}$, cell volume $=2 \mathrm{~mL}$.

Table 1. Binding constants $\left(\mathrm{K}_{\mathrm{b}}\right)$ for interaction of complexes 1-3 with DNA

\begin{tabular}{lccc}
\hline complexes & $\mathrm{K}_{\mathrm{b}} /\left(\mathrm{mol} \mathrm{L}^{-1}\right)^{-1}$ & $\begin{array}{c}(\%) \text { of } \\
\text { Hypochromism }\end{array}$ & $\begin{array}{c}\text { Red shift/ } \\
\mathrm{nm}(\lambda)^{*}\end{array}$ \\
\hline $\mathbf{1}$ & $(3.5 \pm 0.7) \times 10^{4}$ & 12 & $0(356)$ \\
$\mathbf{2}$ & $(4.1 \pm 0.5) \times 10^{4}$ & 19 & $0(327)$ \\
$\mathbf{3}$ & $(2.8 \pm 0.9) \times 10^{4}$ & 12 & $6(319)$ \\
\hline
\end{tabular}

*The peak corresponding to the red shift is shown in brackets.

$\mathbf{1}$ and $\mathbf{2}$, while complex $\mathbf{3}$ shows $6 \mathrm{~nm}$ of bathocromic shift. The values of the binding constant, $\mathrm{K}_{\mathrm{b}}$, were determined for these complexes as described in the experimental section (Table 1). They are moderate and comparable to those observed for other ruthenium complexes such as
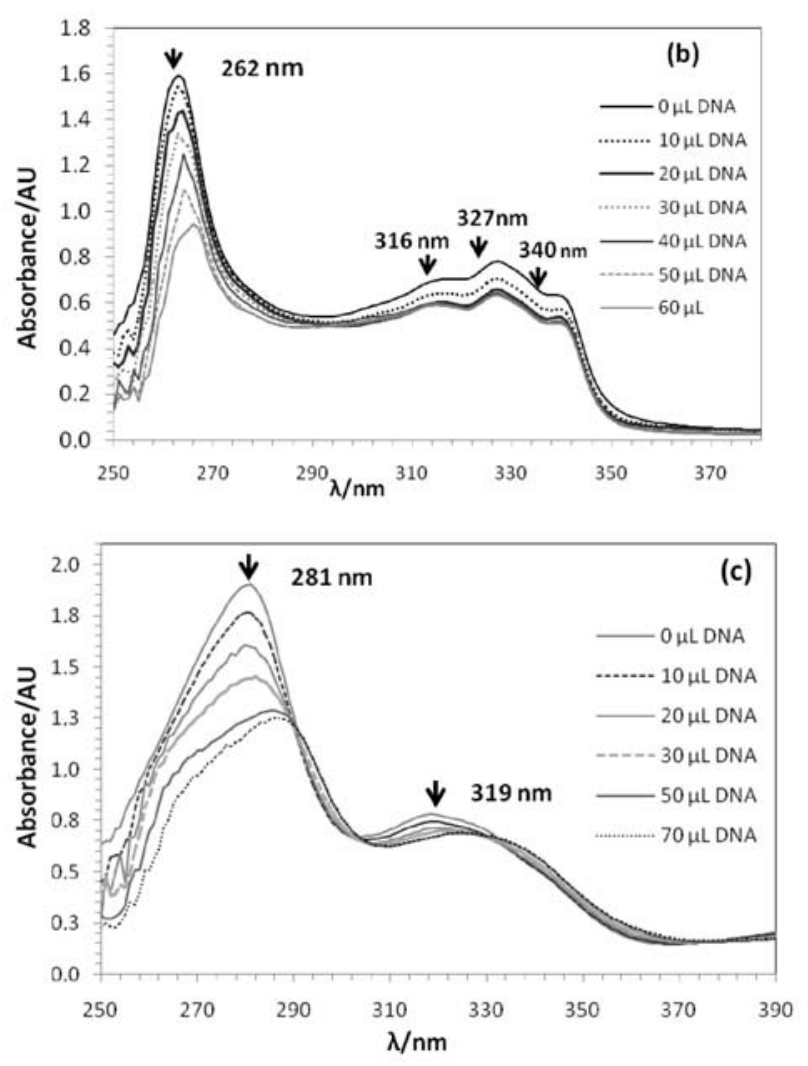

Figure 2. Spectroscopic titrations: (a) 1, (b) 2, (c) 3. [Complex] $=1 \times 10^{-3}$ $\mathrm{mol} \mathrm{L}-1$ and $[\mathrm{DNA}]=1 \mathrm{mg} \mathrm{mL}^{-1}$.

$\left[\mathrm{Ru}(\text { phen })_{2}(\mathrm{phi})\right]^{2+}$, where phi is 9, 10-phenanthrenequinone diimine. ${ }^{25}$ The data indicate that the binding affinities of these complexes to DNA have no significant difference.

It is known that viscosity experiments are sensitive to the change in the length of the DNA double helix. In the absence of NMR and X-ray crystallographic data, ${ }^{26}$ viscosity measurements are considered as one of the most unambiguous methods to determine intercalation or nonintercalation binding of complexes to DNA. The results of viscosity measurements are shown in Figure 3 . The viscosity of DNA remains almost unchanged upon addition of complex $\mathbf{1}$ (shown) or $\mathbf{3}$ (not shown). Complex $\mathbf{2}$ shows an unusual change in the relative viscosity with an increase in the ratio 
[complex]/[DNA]. These results indicate that complexes 1-3 do not intercalate between the DNA bases. Based on the changes of absorbance, fluorescence and viscosity observed for the studied complexes, that are similar to those reported for some ruthenium(II) polypyridine complexes, ${ }^{27,28}$ there may be an interaction with the DNA by electrostatic forces, probably by the groove binding mode. In addition, these complexes could covalently bind to a DNA nucleobase, as does cisplatin. Studies to detect covalent binding will be performed in the future.

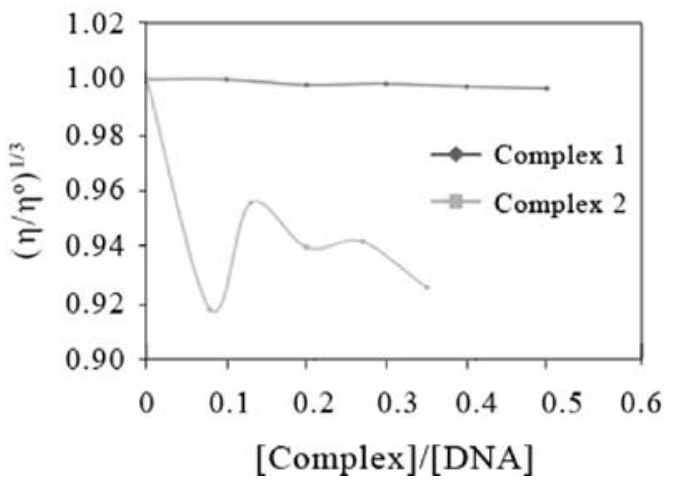

Figure 3. Effect of increasing concentration of complex on the relative viscosity of CT-DNA at $25^{\circ} \mathrm{C}: \mathbf{1}$ (black upper line), $\mathbf{2}$ (gray lower line).

\section{Biological activity on Leishmania (L.) mexicana}

The biological activity essays against Leishmania are described in the experimental section using cultures of promastigotes of Leishmania $(L)$ mexicana, one of the causative species of American cutaneous leishmaniasis. Results summarized in Table 2 show an important parasite growth inhibition induced by the palladium complexes. The leishmanistatic activity $(\mathbf{3} \sim \mathbf{2}>\mathbf{1})$ was associated with motility loss and swelling of parasites that was not observed in control cells, and was comparable to that of $\left[\mathrm{Ru} \text { (bipy) }{ }_{2} \text { (phendiamine) }\right]^{2+} .^{28}$ Electronic microscopy and fluorescence studies similar to tests previously performed for $\mathrm{Cu}, \mathrm{Ag}$ and $\mathrm{Ru}$ complexes are in progress in order to demonstrate the role of parasite DNA as the possible target for the palladium complexes.

Table 2. Biological activity of palladium complexes 1-3 on promastigotes of Leishmania (L.) mexicana in $48 \mathrm{~h}$

\begin{tabular}{lcc}
\hline Complexes & $\begin{array}{c}\text { Cell density/ } \\
\left(10^{6} \text { prom } \mathrm{mL}^{-1}\right)\end{array}$ & $\begin{array}{c}\text { \% of Growth } \\
\text { inhibition }\end{array}$ \\
\hline Control* $^{*}$ & 67 & - \\
$\mathbf{1}$ & 44 & 34 \\
$\mathbf{2}$ & 32 & 52 \\
$\mathbf{3}$ & 28 & 58 \\
\hline
\end{tabular}

* DMSO $0.5 \%(\mathrm{v} / \mathrm{v})$ was added to control cells.

\section{Conclusions}

Palladium polypyridyl complexes were synthesized and their characterizations were achieved through elemental analysis, UV-VIS, IR and ${ }^{1} \mathrm{H}$ NMR spectroscopies. DNA interaction studies showed that complexes 1-3 do not intercalate between the DNA bases. Based on the results of the optical changes and viscosity measurements, it is suggested that they may interact with the DNA by electrostatic forces. Additionally, these complexes induced an important leishmanistatic effect on $L$. (L.) mexicana promastigotes.

\section{Experimental}

All procedures were routinely carried out under $\mathrm{N}_{2}$ using common Schlenk techniques. Ethanol, dichloromethane, acetonitrile and diethyl ether were purified by standard procedures immediately prior to use. All other commercial reagents were used without further purification. The compounds 1,10-phenantroline-5,6dione, ${ }^{29}$ 1,10-phenantroline-5,6-diamine(phendiamine), ${ }^{30}$ dipyrido[3,2-d: 2',3'-f]quinoxaline (dpq), ${ }^{31}$ dipyrido[3,2-a: $2^{\prime}, 3^{\prime}$-c $]$ phenazine $(\mathrm{dppz})^{32}$ and $\left[\mathrm{PdCl}_{2}\left(\mathrm{NCC}_{6} \mathrm{H}_{5}\right)_{2}\right]^{33}$ were synthesized by previously reported methods. Complexes $\left[\mathrm{PdCl}_{2}\right.$ (biquinoline) $]$ and $\left[\mathrm{PdCl}_{2}\right.$ (phen) $]$ were prepared through a modification of a previous reported procedure. ${ }^{34-35}$ NMR spectra were obtained in a DMSO- $d_{6}$ solution in a Bruker AVANCE 300 spectrometer, ${ }^{1} \mathrm{H}$ NMR shifts being recorded relative to residual resonance in the deuterated solvent at $\delta 2.9 \mathrm{ppm}, 298 \mathrm{~K}$. IR spectra were obtained with a Nicolet Magna IR 560 spectrometer. Calf thymus DNA (CT DNA, SIGMA type I) and cellulose dialysis sacks (SIGMA 250-7U) were used as received. All the measurements with CT DNA were carried out in Tris-HCl 5 mmol L-1 (pH 7.2), 50 mmol L-1 $\mathrm{NaCl}$ buffer. The UV absorbance ratio $\lambda_{260} / \lambda_{280}$ was $1.8-1.9$, indicating that the DNA was sufficiently free of protein. ${ }^{36} \mathrm{UV}-\mathrm{VIS}$ spectra were recorded on a HP-8453 spectrophotometer. Emission spectra were recorded on a Shimadzu RF-1501 spectrofluorophotometer.

\section{Synthesis of palladium complexes}

A solution of $\left[\mathrm{PdCl}_{2}\left(\mathrm{NCC}_{6} \mathrm{H}_{5}\right)_{2}\right](1 \mathrm{mmol})$ in $\mathrm{CH}_{2} \mathrm{Cl}_{2}$ $(15 \mathrm{~mL}$ ) was added to $1 \mathrm{mmol}$ of the specific proligand (for complexes $\mathbf{1 , 2 , 4}$, and $\mathbf{5}$ ) in $10 \mathrm{ml}$ of $\mathrm{CH}_{2} \mathrm{Cl}_{2}$. Immediately a solid started to precipitate. The mixture was stirred and kept at $40-45^{\circ} \mathrm{C}$ for a period of 1 to $4 \mathrm{~h}$, after which it was filtered. The solid was washed with $\mathrm{CH}_{2} \mathrm{Cl}_{2}$ and then dried under vacuum. 
$\left[\mathrm{PdCl}_{2}(\right.$ phen $\left.)\right] \cdot \mathrm{H}_{2} \mathrm{O}(\boldsymbol{1})$

Yield $101 \mathrm{mg}(65 \%)$. Anal. Calc. for $\mathrm{C}_{12} \mathrm{H}_{10} \mathrm{Cl}_{2} \mathrm{~N}_{2} \mathrm{OPd}$ : C, 38.37; H, 2.15; N, 7.46\%. Found: C, 38.30; H, 2.28; N, $7.12 \% .{ }^{1} \mathrm{H}$ NMR (DMSO- $\left.d_{6}\right) \delta 9.34\left(2 \mathrm{H}_{A}, \mathrm{~d}, J_{A B} 5.3 \mathrm{~Hz}\right)$; $8.97\left(2 \mathrm{H}_{C}, \mathrm{~d}, J_{C B} 8.2 \mathrm{~Hz}\right) ; 8.30(1 \mathrm{H}, \mathrm{s}) ; 8.14\left(2 \mathrm{H}_{B}, \mathrm{dd},{ }^{1} J_{B A}\right.$ $5.3 \mathrm{~Hz}$ and $\left.{ }^{2} J_{B C} 8.2 \mathrm{~Hz}\right)$. IR(KBr) $v_{\max } / \mathrm{cm}^{-1} 1630(\mathrm{C}=\mathrm{C})$, $1583(\mathrm{C}=\mathrm{N}) . \lambda_{\max } / \mathrm{nm}(\mathrm{DMSO}) 278\left(\varepsilon / \mathrm{dm}^{3} \mathrm{~mol}^{-1} \mathrm{~cm}^{-1}\right.$ $\left.18.6 \times 10^{3}\right)$.

\section{$\left[\mathrm{PdCl}_{2}\right.$ (biquinoline)] $1 / 2 \mathrm{H}_{2} \mathrm{O}(2)$}

Yield $113 \mathrm{mg}$ (72\%). Anal. Calc. for $\mathrm{C}_{18} \mathrm{H}_{13} \mathrm{Cl}_{2} \mathrm{~N}_{2} \mathrm{O}_{0.5} \mathrm{Pd}$ : C, 48.85; H, 2.96; N, 6.33\%. Found: C, 48.56; H, 2.78; N, $6.26 \% .{ }^{1} \mathrm{H}$ NMR (DMSO- $\left.d_{6}\right) \delta 8.80\left(2 \mathrm{H}_{\mathrm{F}}, \mathrm{d}, J_{F E} 8.6 \mathrm{~Hz}\right)$; $8.58\left(2 \mathrm{H}_{\mathrm{E},} \mathrm{d}, J_{E F} 8.6 \mathrm{~Hz}\right) ; 8.18\left(2 \mathrm{H}_{\mathrm{A}}, \mathrm{d}, J_{A B} 8.4 \mathrm{~Hz}\right) ; 8.07$ $\left(2 \mathrm{H}_{\mathrm{D}}, \mathrm{d}, J_{D C} 8.0 \mathrm{~Hz}\right) ; 7.86\left(2 \mathrm{H}_{\mathrm{B}}, \mathrm{t}, J_{B A} 8.5 \mathrm{~Hz}\right.$ and $J_{B C} 6.9$ $\mathrm{Hz}) ; 7.69\left(2 \mathrm{H}_{\mathrm{C}}, \mathrm{t}, J_{C B} 6.9 \mathrm{~Hz}\right.$ and $\left.J_{C D} 7.9 \mathrm{~Hz}\right)$. IR (KBr) $v_{\max } / \mathrm{cm}^{-1} 1614(\mathrm{C}=\mathrm{C}), 1581(\mathrm{C}=\mathrm{N}) \cdot \lambda_{\max } / \mathrm{nm}(\mathrm{DMSO}) 263$ $\left(\varepsilon / \mathrm{dm}^{3} \mathrm{~mol}^{-1} \mathrm{~cm}^{-1} 51.8 \times 10^{3}\right), 327\left(25.1 \times 10^{3}\right)$.

\section{$\left[\mathrm{PdCl}_{2}\right.$ (phendiamine)] $1 / 2 \mathrm{H}_{2} \mathrm{O}(3)$}

A solution of $\left[\mathrm{PdCl}_{2}\left(\mathrm{NCC}_{6} \mathrm{H}_{5}\right)_{2}\right](92 \mathrm{mg}, 0.24 \mathrm{mmol})$ in $\mathrm{CH}_{3} \mathrm{CN}(15 \mathrm{~mL})$ was added to $46 \mathrm{mg}(0.219 \mathrm{mmol})$ of phendiamine in $10 \mathrm{~mL}$ of $\mathrm{CH}_{3} \mathrm{CN}$. Immediately an orange solid started to precipitate. The mixture was stirred at $55^{\circ} \mathrm{C}$ for a period of $4 \mathrm{~h}$, after which it was filtered. The black solid was washed with diethyl ether and then dried under vacuum. Yield $72 \mathrm{mg}(85 \%)$. Anal. Calc. for $\mathrm{C}_{12} \mathrm{H}_{11} \mathrm{Cl}_{2} \mathrm{~N}_{4} \mathrm{O}_{0.5} \mathrm{Pd}: \mathrm{C}, 36.09 ; \mathrm{H}, 2.76 ; \mathrm{N}, 14.04 \%$. Found: $\mathrm{C}, 36.46 ; \mathrm{H}, 2.34 ; \mathrm{N}, 14.11 \% .{ }^{1} \mathrm{H}$ NMR (DMSO- $\left.d_{6}\right) \delta$ $8.97\left(2 \mathrm{H}_{\mathrm{A}}, \mathrm{d}, J_{A B} 5.2 \mathrm{~Hz}\right) ; 8.83\left(2 \mathrm{H}_{\mathrm{C}}, \mathrm{d}, J_{C B} 8.6 \mathrm{~Hz}\right) ; 7.87$ $\left(2 \mathrm{H}, \mathrm{dd}, J_{B C} 8.6 \mathrm{~Hz} ; J_{B A} 5.2 \mathrm{~Hz}\right) ; 5,78(4 \mathrm{H}, \mathrm{s})$. IR (KBr) $v_{\max } / \mathrm{cm}^{-1}: 1636(\mathrm{C}=\mathrm{C}), 1584(\mathrm{C}=\mathrm{N}), 3392,3310\left(\mathrm{NH}_{2}\right)$. $\lambda_{\max } / \mathrm{nm}$ (DMSO): 319, 281 .

\section{$\left[\mathrm{PdCl}_{2}(\mathrm{dpq})\right](\mathbf{4})$}

Yield $91 \mathrm{mg}(96 \%)$. Anal. Calc. for $\mathrm{C}_{14} \mathrm{H}_{9} \mathrm{Cl}_{2} \mathrm{~N}_{4} \mathrm{O}_{0.5} \mathrm{Pd}$ : C, 40.19; H, 2.15; N, 13.40\%. Found: C, 40.00; H, 2.15; N, 12.65\%. IR (KBr) $v_{\max } / \mathrm{cm}^{-1}: 1634(\mathrm{C}=\mathrm{C}), 1573(\mathrm{C}=\mathrm{N})$.

\section{$\left[\mathrm{PdCl}_{2}(\mathrm{dppz})\right](\mathbf{5})$}

Yield $167 \mathrm{mg}(99 \%)$. Anal. Calc. for $\mathrm{C}_{18} \mathrm{H}_{12} \mathrm{Cl}_{2} \mathrm{~N}_{4} \mathrm{OPd}$ : C, 45.26; H, 2.11; N, 11.73\%. Found: C, 45.61; H, 2.07; N, $11.51 \%$. IR $(\mathrm{KBr}) v_{\max } / \mathrm{cm}^{-1}: 1614(\mathrm{C}=\mathrm{C}), 1581(\mathrm{C}=\mathrm{N})$.

\section{DNA interaction studies}

In these studies the complexes were dissolved in DMSO and then diluted to the desired concentration with buffer.

The spectroscopic titrations were carried out in a quartz cell by adding increasing amounts of CT DNA to a solution of the complex at a fixed concentration, and recording the
UV-Vis spectrum after each addition. The intrinsic binding constant $\mathrm{K}_{\mathrm{b}}$ was determined from the plot of [DNA] $/\left(\varepsilon_{\mathrm{a}}-\varepsilon_{\mathrm{f}}\right)$ versus [DNA], where [DNA] is the concentration of DNA in base pairs, and the apparent absorption coefficients, $\varepsilon_{\mathrm{a}}, \varepsilon_{\mathrm{f}}$, and $\varepsilon_{\mathrm{b}}$, correspond to $\left.\mathrm{A}_{\mathrm{obs}} / \mathrm{Pd}\right]$, the extinction coefficient for the free palladium complex, and the extinction coefficient for the palladium complex in the totally bound form, respectively. The data were fitted to equation 1 , with a slope equal to $1 /\left(\varepsilon_{\mathrm{b}}-\varepsilon_{\mathrm{f}}\right)$ and $\mathrm{y}$-intercept equal to $1 /\left(\mathrm{K}_{\mathrm{b}}\left(\varepsilon_{\mathrm{b}}-\varepsilon_{\mathrm{f}}\right)\right.$, and $\mathrm{K}_{\mathrm{b}}$ was obtained from the ratio of slope to intercept. ${ }^{37}$

$[\mathrm{DNA}] /\left(\varepsilon_{\mathrm{a}}-\varepsilon_{\mathrm{f}}\right)=[\mathrm{DNA}] /\left(\varepsilon_{\mathrm{b}}-\varepsilon_{\mathrm{f}}\right)+1 /\left(\mathrm{K}_{\mathrm{b}}\left(\varepsilon_{\mathrm{b}}-\varepsilon_{\mathrm{f}}\right)\right)$

Luminescence studies were carried out by adding increasing amounts of CT DNA to a solution of the palladium complex at a fixed concentration contained in a quartz cell. Complexes 1, 2 and $\mathbf{3}$ were excited at 320, 340 and $341 \mathrm{~nm}$ respectively, and fluorescence spectra were observed between 650 and $750 \mathrm{~nm}$.

Viscosity measurements were carried out with an Ostwald viscometer, immersed in a water bath maintained at $24{ }^{\circ} \mathrm{C}$. DNA was previously sonicated for periods of 1 min. ${ }^{38}$ DNA concentration was kept constant in all samples, but complex concentration was increased. Flow time was measured with a digital chronometer. The average of four flow measurements was used. Data are presented as $\left(\eta / \eta^{0}\right)^{1 / 3}$ versus the ratio [complex]/[DNA], where $\eta$ is the viscosity of DNA in the presence of the complex and $\eta_{0}$ is the viscosity of DNA alone. Viscosity values were calculated from the observed flow time of DNA-containing solutions corrected for the flow time of buffer alone $\left(\mathrm{t}_{0}\right)$ : $\eta=t-\mathrm{t}_{0}$.

\section{Biological activity on Leishmania (L.) mexicana}

Leishmania (L.) mexicana promastigotes (NR strain, isolated in 1980 from a human patient with diffuse cutaneous leishmaniasis at the Instituto de Biomedicina, Universidad Central de Venezuela) were used. They were maintained at $26{ }^{\circ} \mathrm{C}$ in Schneider's Drosophila medium (Sigma, St. Louis MO, USA) supplemented with 5\% heat inactivated fetal calf serum (GIBCO-BRL, Grand Island, NY, USA) and were treated with the palladium complexes 1-3 dissolved in DMSO (Rieder-de-Haen, Germany). Control cells were treated with DMSO only, at the same concentration used with the complexes $[0.5 \%(\mathrm{v} / \mathrm{v})]$. The complexes were added when the cultures reached $10^{7}$ parasites $\mathrm{mL}^{-1}$ in the exponential phase of growth at $10 \mu \mathrm{mol} \mathrm{\textrm {L } ^ { - 1 }}$ final concentration. Growth inhibition was monitored during $48 \mathrm{~h}$ by direct counting in a Neubauer chamber, and viability was measured by trypan blue exclusion (Sigma St. Louis MO, USA). 


\section{Acknowledgments}

The authors wish to thank Lic. William Castro, TSU Alberto Fuentes, Dr. Paul Berger and Dr. Hilda Torin for their assistance.

\section{References}

1. Blum, J.; Desjeux, P.; Schwartz, E.; Beck, B.; Hatz, C.; J. Antimicrob. Chemother. 2004, 53, 158.

2. Olliaro, P.; Bryceson, A.; Today 1993, 9, 323.

3. Kinnamon, K.; Steck, E. A.; Rane, D. S.; Antimicrob. Agents Chemother. 1979, 15, 157.

4. Farrell, N. P.; Willianson, J.; MacLaren, D. J. M.; Biochem. Pharmacol. 1984, 33, 961.

5. Brown, R. In Critical Reports on Applied Chemistry: Chemotherapy of Tropical Diseases, Hooper M., ed.; John Wiley \& Sons: Chichester, 1987, 72.

6. Mbongo, N.; Loiseau, P. M.; Craciunescu, D. G.; Robert-Gero, M.; Acta Tropica 1998, 70, 239.

7. Sánchez-Delgado, R. A.; Lazardi, K.; Rincón, L.; Urbina, J. A.; Hubert, A. J.; Noels, A. F.; J. Med. Chem. 1993, 36, 2041.

8. Navarro, M.; Pérez, H.; Sánchez-Delgado, R. A.; J. Med. Chem. 1997, 40, 1937.

9. Sánchez-Delgado, R. A.; Navarro, M.; Lazardi, K.; Atencio, R.; Capparelli, M.; Vargas, F.; Urbina, J. A.; Bouillez, A.; Hubert, A. J.; Noels, A. F.; Inorg. Chim. Acta 1998, 275, 528.

10. Navarro, M.; Lehmann, T.; Cisneros-Fajardo, E. J.; Fuentes, A.; Sanchez-Delgado, R. A.; Silva, P.; Urbina, J. A.; Polyhedron 2000, 19, 2319.

11. Navarro, M.; Cisneros-Fajardo, E. J.; Lehmann, T.; SanchezDelgado, R. A.; Atencio, R.; Silva, P.; Lira, R.; Urbina, J. A.; Inorg. Chem. 2000, 40, 6879.

12. Erkkila, K. E.; Odom, D. T.; Barton, K. J.; J. Chem. Rev. 1999, 99, 2777.

13. Farrell, N. In Transition Metal Complexes as Drugs and Chemotherapeutic Agents, in Catalysis by Metal Complexes; James, B. R.; Ugo, R., eds.; Kluwer: Dordrecht, 1989, ch. 1 - 4.

14. Abu-Surrah, A. S.; Al-Allaf, T. A. K.; Rashan, L. J.; Klinga, M.; Leskela, M.; Eur. J. Med. Chem. 2002, 37, 919.

15. Budzisz, E.; Krajewska, U.; Rozalski, M.; Szulawska, A.; Czyz, M.; Nmawrot. B.; Eur. J. Pharmacol. 2004, 502, 59.

16. Navarro, M.; Prieto-Peña, N.; Colmenares, I.; Gonzalez, T.; Arsenak, M.; Taylor, P.; J. Inorg. Biochem. 2006, 100, 152.

17. Rebolledo, A. P.; Vieites, M.; Gambino, D.; Piro, O. E.; Castellano, E.; Zani, C. L.; Souza-Fagundes, E. M.; Teixeira, L. R.; Batista, A. A.; Beraldo, H.; J. Inorg. Biochem. 2005, 99, 698.
18. Gómez-Quiroga, A.; Navarro-Ranninger, C.; Coord. Chem. Rev. 2004, 248, 119.

19. Navarro, M.; Cisneros-Fajardo, E.; Fernandez-Mestre, M.; Sierraalta, A.; Silva, P.; Arriechi, D.; Marchan, E.; J. Biol. Inorg. Chem. 2003, 8, 401.

20. Navarro, M.; Cisneros-Fajardo, E.; Fernandez-Mestre, M.; Arriechi, D.; Marchan E.; J. Inorg. Biochem. 2003, 97, 364.

21. Navarro, M.; Cisneros-Fajardo, E.; Marchan, E.; Drugs. Res. 2006, 56, 600.

22. Navarro, M.; Hernandez, C.; Colmenares, I.; Hernandez, P.; Fernandez, E.; Sierraalta, A.; Marchan E.; J. Inorg. Biochem 2007, 101, 111.

23. Wilkinson, G.; Comprehensive Coordination Chemistry, Pergamon: London, 1987, 5, ch. 51.

24. Xiao-Hua, Z.; Bao-Hui, Y.; Hong, L.; Quian-Ling, Z.; Hui, C.; Jin-Gang, L.; Liang-Nian, J.; Xiao-Yuan, L.; J. Biol. Inorg. Chem. 2001, 6, 143.

25. Barton, J. K.; Danisshefsky, A. T.; Golberg, J. M.; J. Am. Chem. Soc. 1984, 106, 143.

26. Satyanarayana, S.; Dabrowiak, J. C.; Chaires, J. B.; Biochemistry 1992, 31, 9319.

27. Xiong, Y.; Ji, L. N.; Coord. Chem. Rev. 1999, $185,711$.

28. Navarro, M.; Corona, O. A.; Colmenares, I.; Marchan, E.; Lett. Drug Des. Discovery 2006, 7, 454.

29. Calderazzo, F.; Marchetti, F.; Pampaloni, G.; Passaelli, V.; J. Chem. Soc., Dalton Trans. 1999, 24, 4389.

30. Bodige, S.; MacDonnell, F. M.; Tetrahedron Lett. 1997, 38, 8159.

31. Collins, J. G.; Sleeman A. D.; Aldrich-Wright, J. R.; Greguric, I.; Hambley, T. W.; Inorg. Chem. 1998, 37, 3133.

32. Dickeson, J. E.; Summers, L. A.; Aust. J. Chem. 1970, 23, 1023

33. Doyle, J. R.; Slade, P. E.; Jonassen, H. B. Inorg. Synth. 1960, $6,216$.

34. Ivanov, M. A.; Puzyk, M. V.; Balashev, K. P. Opt. Spectrosc. 2006, 101, 105.

35. Klein, R. A.; Belzen, R. V.; Vrieze, K.; Elsevier, C. J.; Thummel, R. P.; Fraanje, J.; Goubitz, K.; Collect. Czech. Chem. Commun. 1997, 62, 238.

36. Marmur, J.; J. Mol. Biol. 1961, 3, 208.

37. Wolfe, A.; Shimer, G. H.; Maehan, T.; Biochemistry 1987, 26, 6392.

38. http://hdklab.wustl.edu/lab_manual/southern/southern8.html, accessed in June 1990

Received: June 28, 2007 Web Release Date: August 20, 2008 